\title{
Transgressing Boundaries: Belfast and the 'Romance-Across-the-Divide'
}

\author{
By Stephanie Schwerter \\ School of Literature and Languages, Coleraine \\ University of Ulster
}

Copyright (c) 2007 by Stephanie Schwerter. This text may be archived and redistributed both in electronic form and in hard copy, provided that the author and journal are properly cited and no fee is charged for access.

\begin{abstract}
One of the most popular sub-genres of Northern Irish Troubles fiction is the so called 'Romance-across-the-divide', a narrative in which two characters from different religious, cultural and social backgrounds struggle to overcome the region's sectarian divide. As the centre of the Northern Irish conflict, Belfast epitomises the obstacles posed by the political situation for lovers attempting to defy socio-cultural and denominational boundaries. Joe Cleary argues that in the Northern Irish context the romance narrative is employed to illustrate the possibility of a reconciliation of opposed political camps. This article attempts to refute Cleary's view. Focussing on Naomi May's Troubles (1976), Dermot Healy's A Goat's Song (1994) and Kate O’Riordan's Involved (1995) it sets out to demonstrate that unhappy unions of lovers cutting across sectarian lines serve instead largely to depict the ongoing political division within Northern Irish society and the breach between the North and the South of Ireland.
\end{abstract}

Key Words. Northern Ireland, Troubles, sectarianism, romance-across-the-divide, Naomi May, Kate O’Riordan, Dermot Healy

Resumen. Uno de los subgéneros más populares de la narrativa surgida en torno a los Disturbios de Irlanda del Norte es el llamado 'Romance más allá de la divisoria', una historia en la que dos personajes de ambientes sociales, culturales y religiosos diferentes intentan superar la divisoria sectaria de la región. Como centro del conflicto norirlandés, Belfast deviene un epítome de los obstáculos que la situación política impone sobre esos amantes que tratan de desafiar las barreras socioculturales y sectarias. Joe Cleary ha afirmado que en el contexto norirlandés este tipo de narrativa se emplea para ilustrar la posibilidad de una reconciliación entre campos políticos opuestos. Este artículo intenta refutar dicha opinión. Centrándose en Troubles (1976) de Naomi May, A Goat’s Song (1994) de Dermot Healy y Involved (1995) de Kate O’Riordan, se propone demostrar hasta que punto el fracaso en la unión de esos amantes a un lado y otro de las barrera religiosa sirve de hecho para exponer la división aún existente dentro de la sociedad norirlandesa, así como la brecha entre el Norte y el Sur de Irlanda.

Palabras clave. Irlanda del Norte, conflicto norirlandés, sectarianismo, 'romance al otro lado de la divisoria’, Naomi May, Kate O’Riordan, Dermot Healy, Joan Lingard.

The Northern Irish Troubles have given rise to a remarkable variety of prose dealing with the influence of political violence on society.
Formally and thematically concentrating on diverse aspects of the conflict, authors have chosen different fictional forms, such as the

ISSN 1699-311X 
thriller, the romance or political fiction, in order to insert their personal voice into the discourse on the Northern Irish tensions. A frequently employed literary mode to illustrate the consequences of the conflict is the "Romance-across-the-divide" (Cleary 1996: 238) or "Love-across-the-barricades story" (Kennedy-Andrews 2003: 90), a narrative in which two representatives of the antagonistic religious communities try to surmount the obstacles posed by political violence and religious bigotry to form a relationship. The term 'barricades', in this context, refers not only to the physical barriers erected to keep Protestants and Catholics apart, but also is an allusion to the mental alienation of the two political camps. The 'Romance-across-thedivide' exploits the distinction between public and private spheres in order to exhibit the consequences of sectarianism (Cleary 1996: 238-244). Reflecting the region's problems in their most concentrated form, Belfast becomes a popular setting for boundary crossing relationships.

Joe Cleary maintains that the interest and appeal of these narratives is "their drive to imagine some kind of reconciliation between the two conflicting communities in Northern Ireland” (1996: 238). I shall challenge Cleary's view and argue that the 'Romance-across-thedivide' is mostly used to express the impossibility of a political reconciliation. I argue here that Belfast is employed to exhibit the region's political tensions by being presented as an obstacle for lovers attempting to overcome religious barriers. The city's sectarian division, depicted as an insurmountable hurdle for characters from different religious backgrounds, operates as a metaphor for the unattainable rapprochement of the two political camps. Common perceptions of Belfast's inhabitants as doomed to their "luckless and predetermined fate" (Cleary 1999: 502) are not revised but confirmed. Concentrating on Naomi May's Troubles, Dermot Healy's A Goat's Song and Kate O'Riordan's Involved, this article attempts to examine the different ways in which the Northern Irish tensions hinder "transgressive union of lovers" (Cleary 1996: 250). Written and set at different times of the conflict, the three novels show the authors' concern to shift the narrative focus from the clashes of two conflicting communities towards a larger vision of the Troubles entangling wider socio-political matters in their respective love stories.

According to Cleary, the "romance which straddles the political divide" presents an "anxious and contradictory literary mode", in which "national romance" and "domestic fiction” fuse (1996: 238). 'Domestic fiction', in this context, refers to narratives in which political and private spheres are detached from each other, and personal relationships receive thematic precedence over political aims. The term 'national romance', on the contrary, applies to novels in which the union of two lovers from opposed communities comes to represent the consolidation of a multinational state (Cleary 1996: 239-240). The Northern Irish 'Romance-across-the-divide', however, cannot be seen as a fully-fledged 'national romance': "In Northern Ireland . . . the consolidation of the state is the goal of only one party to the conflict (the unionist community) while the goal of the other (the nationalist community) is not to consolidate the state but to abolish or fundamentally restructure it” (Cleary 1996: 239). Consequently, the union of partners with different religious backgrounds does not imply the confirmation of Northern Ireland's status quo, but hints at a possible reconciliation of the two communities in whichever way. The particular circumstances of the Northern Irish conflict have generated a hybrid narrative form in which the "political tale of the 'national romance"” and the "antipolitical tale of escape into domestic privacy” meet (Cleary 1996: 241).

According to Cleary, Joan Lingard's series of children's books on the Northern Irish situation functions as a paradigm for romance narratives written afterwards. Lingard's novels were published at an early stage of the conflict and still appear in the curricula of both, British and Irish secondary schools. Cleary argues that Lingard's cycle cannot be dismissed as "inconsequential children's fiction" as its influence on the discourse on the Northern Irish conflict is far-reaching: “. . . these novels . . . set up an elementary matrix of discursive spaces through which we can observe in X-ray or negative relief . . . a mode of narrative organization that would recur, sometimes in more complex variations, not only in literature but also in political and social-scientific 
writings on the Northern Irish conflict" (1996: 245). Despite their belonging to the genre of children's fiction, Lingard's novels present a thematic model for romance narratives set in Northern Ireland and therefore will be referred to in the following analysis of Troubles, A Goat's Song and Involved.

Lingard's cycle commences with the novel Across the Barricades which is set in workingclass Belfast. The action develops around the Northern Irish Catholic boy Kevin and the Protestant girl Sadie, who, after a long struggle, finally manage to break free from the influence of their respective communities. However, their union can only happen outside Northern Ireland (Lingard 1972). Whereas Lingard concentrates on the sectarian divide between Catholicism and Protestantism, Troubles, A Goat's Song and Involved also touch on cultural, social and gender divides. The three novels are complex variations on Lingard's model, which each underscore the impossibility of a political reconciliation by showing Belfast's destructive influence on the individual love stories ${ }^{1}$.

May's Troubles was published in 1976. The novel's action is set in Belfast at the time of the first outbreak of the conflict. As in Lingard's cycle, the hero and the heroine are representatives of the two conflicting communities in Northern Ireland. However, they do not have a working-class background: the Catholic Catherine Hardwicke belongs to an old noble family and the Protestant John Mulholland is the son of a rich factory owner. Whereas in Across the Barricades the Northern Irish conflict poses an obstacle for the two lovers' coming together, in Troubles an already existing relationship is destroyed by the eruption of political violence. May not only dwells on sectarianism, but equally integrates class and gender differences into her narrative. The author draws attention to the fact that in Belfast's society religious boundaries coincide

\footnotetext{
1 Jennifer Johnston's Shadows on our Skin (1977) and Bernard McLaverty's Cal (1983) are further narrative examples which can be read as variations on Lingard's cycle. Even recent children's books such as Kate McLachlan's Love My Enemy (2004) take the form of the 'Romance-across-the divide'. The success of Neil Jordan's The Crying Game (1992) shows that boundary crossing relationships are of topic interest also in film.
}

with "the cleavages in national identity, political aspiration and cultural background" (Morgan and Smyth 1996: 10). In the course of the novel, religion increasingly turns into a fundamental marker of division that includes other potent forces.

Before the onset of the Troubles, Catherine and John's love crosses the city's religious divide. The two main characters maintain a happy relationship as long as they manage to withdraw from the influence of their respective communities and retreat into domestic life. Nevertheless, as soon as politics enter their private sphere, the couple's inter-faith marriage starts to crumble. Caused by the escalating situation, Catherine and John's gradual alienation reflects the increasing political disunity in Belfast's society. After the outbreak of sectarian violence, the couple's home loses its status as a place of refuge. The two spheres of social life, which Gayatri Spivak defines as "public" and "private sector", begin to clash and take on a gender specific meaning (1988: 103). According to Spivak, the "public sector", seen as "political", "social", "professional" and "intellectual" is associated with masculinity, whereas the "private sector" is described as "emotional", "sexual" and "domestic" and is attributed to women (1988: 3). In Troubles, the hero joins the "male" sector of public life through militant political activity and tries to restrict his wife to domestic passivity. As the public sphere is considered to be "more important" and "more rational" (Spivak 1988: 103), it could be argued that John socially elevates himself above his wife by an ever increasing commitment to the active 'male' sector of Belfast's society.

The deterioration of the political situation stirs up disputes about gender roles in the couple's relationship. Catherine's wish to become politically active by supporting impoverished Catholics in West Belfast is belittled by her husband who brings pressure to bear in order to keep her in the domestic sphere:

... after going home and telling John she was going to do meals-on-wheels in the Falls, he had laughed at her idea of a personal peacemission: did she think that all by herself she could solve the Troubles by doing a few hours' charity work - which she would abandon as soon as it became a bore? He did 
not believe in her, she protested. He then cut her off, saying that it was not worth risking her life - did she remember that there might be bullets ricocheting from the wall? - for a sentimental impulse. What about the children? And who would make his tea? (96)

Through his derogatory reaction, John seeks to disallow Catherine the idealism and growing political activism he himself enjoys by reminding her of her domestic duties as wife and mother. At the same time, he displays antagonism towards members of the Catholic community. Whereas John did not mind Catherine's Catholic background before the outbreak of the Troubles, he afterwards adopts an increasingly hostile attitude towards people belonging to the 'other side'. The discord between the two partners, caused by denominational and political difference, echoes the continuing division within Belfast's society. John's negative attitude towards the Catholic community goes along with a growing disrespect for his wife based on her religious background and gender; when Catherine accuses him of discriminating against Catholic employers in his factory, John dismisses her as "an unworthy little girl” (75). Hence, May's novel can be read as a social critique of what Megan Sullivan calls the "troubling intersections of sexism and sectarianism” (1999: 3).

As the action moves on, the political tensions give rise to an "embitterment of personal relationships" (98) and make the partners drift apart. Whereas John becomes increasingly militant and joins the Ulster Defence Regiment, Catherine begins an affair with the married English diplomat Martin Dillon. She finally withdraws into her extra marital private life and renounces politics altogether. The war-torn situation in the city does not interest her any more, but adds to her excitement at having a secret relationship:

... she had become careless of the surrounding danger and, where her friends were doing the Christmas shopping in the villages outside Belfast, she made a point of going into the city and, when she heard an explosion, she thought: If it happens at least I will have lived - I will have been complete! If she were to die tomorrow, she would not have to pay the price when the affair came to an end and Martin's term was over (157).
Catherine flees into a world of illusion in order to escape her unhappy marriage and the pressures of the escalating conflict. Her relationship with Martin crosses a different kind of political divide: the two characters' love affair does not transgress the religious boundaries within Northern Irish society, but can be read as an attempt to overcome the political 'barriers' between Ireland and the United Kingdom.

In contrast to Catherine, who embodies Catholic Ireland, Martin, as a representative of the British government, evokes Protestantism and colonialism. Like her marriage, Catherine's liaison with Martin is ill-fated: after the end of his term, Martin takes up his next post in Tokyo, leaving Belfast with his English wife. Through his refusal to get divorced he gains power over Catherine, who is unable to suppress her feelings for him. Psychologically and emotionally dependent on her lover, Catherine is subject to his decisions. Martin's emotional dominance over Catherine echoes British colonial supremacy over Northern Ireland. In the same way as Martin decides over his relationship with Catherine, the British establishment determines the region's fate. Using Martin and Catherine's liaison as a metaphor for British-Irish political relations, May implies that Northern Ireland remains subject to the colonisers' self-interest. The fact that both love stories depicted in the novel are equally doomed to failure points to the impossibility of a political settlement. Hence, May suggests that neither a reconciliation between the two antagonistic communities within Northern Ireland, nor a political entente between the colony and the coloniser, can be reached. The author employs Catherine, John and Martin as representatives of different political camps, and thus transfers the novel's focus from the traditional sectarianism of two opposed communities, to a larger vision of the political relations between all parties involved in the Northern Irish conflict.

The end of the novel is marked by the brutal murder of Catherine's husband. The question, whether John is killed by Republican or Loyalist paramilitaries, however, remains open. Thus, May avoids taking a side in presenting the escalating tensions in Belfast. Catherine's retrospective reflections on her life with John mirror the interconnection between 
the deteriorating situation and the failure of her marriage: "She remembered John playing with the baby on the grass and the grass full of daisies. It seemed inconceivable that the country had been at peace” (226). Juxtaposing the image of John's idyllic play with his son before the outbreak of the Troubles, and his violent death afterwards, May deepens our understanding of Belfast as a place in which a life beyond sectarianism is excluded. With John's unexpected death, the author depicts the conflict as a political struggle whose consequences affect all social classes. May sets her novel in Belfast's middle-class and in this way differs from Lingard's model, in which the Troubles are mainly associated with working-class Catholics and Protestants. She emphasises that the Northern Irish tensions cannot be reduced to a war of two conflicting communities belonging to the same social class.

May's image of Belfast as obstacle for love stories cutting across religious lines reflects a worldview disposed to resignation and despair. This dark picture of the city can be explained by the novel's historical context. In the seventies, the Northern Irish conflict was at its violent height and a settlement of the situation did not seem within reach. Thus, the impossibility of the long term union of lovers from hostile political camps reflects the hopelessness felt during the seventies at the tensest period of the Troubles.

Healy's A Goat's Song was published more than three decades after Lingard's cycle. In his novel, the author does not focus on the conflicting communities within Northern Ireland, but on the cultural differences between the North and the South of Ireland. Unlike Lingard's Across the Barricades and May's Troubles, Healy's novel is set against the background of a more peaceful Belfast, in which bomb explosions and riots no longer dominate the characters' daily life. However, the city is still depicted as seething with its old animosities, which become apparent in the two communities' antagonistic attitude towards each other and in their common rejection of strangers. The plot develops around the Northern Irish Protestant Catherine Adams and the Catholic Jack Ferris from County Mayo. The relationship between the hero and the heroine presents a further narrative example of a "strong nexus between the political and the personal in the Irish context" (Wonderich 1999: 74). The two characters are not only mentally unstable and addicted to alcohol but also unable to come to terms with their different cultural backgrounds. The distinctive feature of the novel, however, is that Jack as a Southerner is extrinsic to the Northern Irish religious divide. Despite his Catholic upbringing Jack does not blend into Belfast's Catholic community: unwritten sectarian rules and laws, naturally followed by Northern Catholics, remain beyond understanding for him. As a result of his Southern Irish background, Jack does not consider religion in terms of politics.

By intertwining the tale of a "love affair between two damaged people" with an account of the detrimental consequences of the conflict, Healy draws a complex picture of the region's sectarian tensions (Mahony 1998: 225). Unlike May, who concentrates on Northern Ireland, Healy sets his narrative in different towns in the North and the Republic. The novel tells the story of the main characters' restless search for a place in which a peaceful life together is possible. Belfast acts as catalyst at a critical stage in the emergence of cultural barriers in their relationship: the couples' problems manifest themselves in their most intense form during Catherine and Jack's stay in the city.

Due to their childhood in different parts of the island, the two characters display various degrees of local knowledge: whereas Catherine is familiar with the territorial and sectarian boundaries of Belfast, Jack as a product of a "post-Nationalistic, post-Catholic, postideological Southern culture", is not able to understand the behaviour of the city's inhabitants (Kennedy-Andrews 2003: 136). Catherine's ability to read the city gives her superiority over Jack and unbalances their relationship. The couple's dwelling place in Protestant East Belfast presents an obstacle for Jack's integration into the local community: perceived as a stranger because of his Southern accent, Jack is called "the Irishman" and categorised as a Catholic (282). In choosing to show Jack as an outsider, Healy throws a critical light on the complexity of Northern Irish sectarianism: the antagonistic political camps also reject foreigners who do not clearly belong to one of the Northern Irish communities. Thus, the author launches an attack on Northern Irish self-centredness 
caused by religious dogmatism and intolerance.

Throughout the course of the novel, signs of political allegiance play an important part as markers of identity. The choice of the 'right' newspaper sparks off a serious argument between the two partners. Forbidding Jack to buy the 'Catholic' Irish News in Protestant East Belfast, Catherine spells out its underlying political connotation:

'Don't be tempted by it,' advised Catherine.

'There's not a soul in this area would be seen dead buying the Irish News.' 'I won't, don't worry.' 'It's left there deliberately to trap a body. That's how they'd know who you are. You've got to take care,' she said adamantly. 'I feel responsible for bringing you here.'

As a place with its own hidden codes and rules, Belfast can only be interpreted by one of the lovers and consequently turns into a source of tensions.

Similarly to May's novel, in A Goat's Song the couple's private sphere does not serve as the "sole domain of authentic existential fulfilment” (Cleary 1996: 240). Instead, it is an arena for the expression of sectarian anxieties as Catherine increasingly worries about her partner's security in Belfast and tries to screen him off from the outside world. In so doing, the heroine enforces in the couple's life an "opposition between the private and the pubic" (Spivak 1988: 103). Whereas Catherine follows her profession as an actress and actively takes part in Belfast's public sphere, Jack, as a Catholic living in the wrong part of the city, is condemned to domestic isolation. In contrast to Troubles, where the female main character is expected to fulfil the role of a “domestic woman" (Amstrong 1987: 3), in A Goat's Song traditional gender roles are reverted and Jack's life becomes restricted to "the private sphere of the domus" (Shields 1996: 238). Thus, the hero is forced into the "female sector" of Belfast's society (Spivak 1988: 103). For Jack, his home in East Belfast does not present a safe haven but turns into a place of loneliness and despair:

Left alone in their house in working-class Belfast he often found a sound he could not place running through his head. It was like the static across the trawler's radio at sea. To drown it out he tried talking to himself. But this 'talking to himself' implied a mild exchange, an off-hand chat. In fact, what he was at amounted to verbal self abuse . . . the sound he was hearing was his own crazy thoughts raging in his ears . . . he began to dread being alone. (271)

As Jack's longing to leave his domestic seclusion increases, the couple's personal life does not present a happy "escape into domestic privacy” (Cleary 1996: 241). Eventually, the relationship is condemned to failure.

For the two partners, Belfast's public sector does not provide a basis for a peaceful life either. As a "complex system of social relationships” the city's territorial segregation reflects its religious divide (Howe 1971: 64). Jack intentionally ignores Belfast's sectarian fragmentation and carelessly navigates through different parts of the city. His reckless attitude increasingly provokes tensions between the two partners:

\begin{abstract}
'A soldier winked at me the other day. On the Lower Falls Road.' 'And what were you doing up there?' 'Walking about.' 'Yes, indiscriminately.' 'And then I always go through the barriers a few times.' 'Why?' 'I love being searched.' 'So, that's how you get your thrills.' She tapped her cigarette onto the windowsill. 'I'm sure your Sinn Fein friends would not be enamoured to hear about your perverse nature. All you Civil Rights marchers are just old hippies, aren't you?' 'That's right,' said Jack. (286)
\end{abstract}

Disparagingly calling Jack a "Civil Rights marcher”, Catherine attributes to her partner a nationalist attitude. Jack, however, as an apolitical thinking individual from the South, identifies with neither British Unionism nor Irish Nationalism. Catherine's attempt to pigeonhole her partner along the political lines that dominate the North reflects her unwillingness to accept Jack's different cultural background. The influence of politics on the lovers' private life increasingly creates mental and emotional barriers between them. Catherine and Jack's different mindsets echo the alienation between the North and the South of Ireland.

On account of his Southern Irish upbringing, Jack is not used to the Northern Irish habit of classifying every individual according the two religious communities. He looks down on the Northerners and uses their internal tensions in order to mock them. When a drinking companion asks him whether he is a 
Republican, Jack answers "I'm just a dancer" (296). Whereas in front of his Catholic neighbour Jack claims to be a Mohammedan, in a Loyalist bar he provokes a fight pretending to be a Protestant:

'What religion are you?' ... 'I'm Protestant,' Jack answered. 'You don’t fool me!' Jack saw people were leaving the bar very fast . . . The man leaned forward to Jack. 'You are probably one fucking Provo. I can see it in your eye.' He moved closer to Jack. 'I've looked into many a terrorist's eye, in Israel and in Cyprus, and I know one when I see one.' Jack protested. 'You see this gat?' said Bertie lifting his jacket to show a gun in the back of his trousers. 'You see this gat? I'll soon know who you are.' (328)

Jack gradually becomes an outcast as he does not fit into either community. Through the depiction of Jack as a rejected individual, Healy criticizes the religious rigidity ingrained in Belfast's society. Only being able to think in terms of sectarianism, the city's inhabitants are illustrated as narrow-minded and bigoted.

The pressures and fears imposed upon the couple by sectarianism result in constant fighting and excessive consumption of alcohol. Unable to cope with the situation, Jack escapes from Belfast and leaves Catherine. The breakdown between the hero and the heroine reflects the insoluble cultural divide between the North and the South of Ireland intensified by the Troubles. The North has generated its own violent culture, which, it could be argued, is ignored by many in the Republic. The couple's discord can be read as a symbolic projection of the conflicting moral and political value systems adhered to in the different parts of the island. In this context, the protagonists' failed attempt to overcome cultural boundaries operates in terms of a metaphor for an unachievable reunification of Northern Ireland and the Republic. Consequently, Healy's novel works against the narrative image of reconciliation, which Cleary considers a common feature of the "Romance-across-thedivide" (1996: 238). In A Goat's Song the hope for a mutual understanding is reduced to ashes. Thus, the novel can be interpreted as a criticism of the devastating influence of Northern sectarianism.

Similarly to A Goat's Song, O'Riordan's Involved belongs to "narratives which ring more complex variations of the romance- across-the-divide” (Cleary 1996: 246). Again, opposing characters from the South and the North of Ireland, O'Riordan diverges from Lingard's model in which the disputes of two Northern Irish communities are central to the plot. Published in 1995, the narrative develops around the Northern Irish Catholic Danny and the Protestant Kitty from County Cork. Although cultural boundaries play an important part in the development of the action, the novel mainly touches on the decisive influence of class differences. Therefore, the main characters' relationship presents a "transgressive union of lovers" (Cleary 1996: 250) in more than one way: coming from different parts of the island and from different social milieus, Danny and Kitty challenge cultural and social barriers to the same extent. In contrast to Kitty, a daughter of a rich family, Danny belongs to Belfast's Republican working-class. Over the course of the novel, social differences become increasingly important. Whereas at the beginning Danny teases Kitty about "her posh flat in Ballsbridge paid for by 'Daddy", as the action moves on, the social differences between the two characters turn into an insurmountable obstacle to their relationship (39). Danny feels misunderstood and accuses Kitty of not having any notions about his social background:

'You don't know the first thing about where I come from, it might just as well be the other side of the moon for all you know with your pretty little pictures of grimy streets full of fanatics and madmen. I laugh when I hear you talking about Belfast. Laugh - d'you hear me? To the likes of you and your bloody 'Daddy' we're all not much better than some strain of fucking mongrels. Not part of that lot and not part of your lot. With our funny accents and lust for killing . . . I've seen the way you look at the lads in my flat. Like they were bacteria or something . . . I'm not a fool you know. I know what you think of them ... of us ...' (43)

Seeing Kitty’s lack of sympathy as a result of her middle-class upbringing, Danny attributes their discords to social differences. Through his heated reaction to Kitty's ignorance, Danny expresses his strong identification with his home.

The class discrepancies between the two characters reach their height during the couples' visits to Belfast. As a representative 
of the Southern Irish middle-class, Kitty is not taken seriously in the circle of Danny's friends and family. Danny's Republican drinking companions answer Kitty's questions in "a ridiculous parody of posh English accent" in order to mock her (85). Their grotesque imitation of Kitty's Southern middle-class accent demonstrates their rejection of Danny's partner. Displaying a hostile attitude towards a representative of the Republic, Danny's friends paradoxically reject the part of Ireland with which they identify ideologically. Their negative reaction to Kitty's middle-class background highlights the social gap between working and middle-class. Consequently, the Northern Irish conflict is illustrated as a fight carried out between two antagonistic workingclass camps which resent the hands-off attitude adopted by sections of the middle-class in an "ideological" dispute. Kitty's attempt to defend herself against Danny's friends amounts to a political offence: "I don't know what the joke is -all this posh voice but- after all, I'm the one who is really Irish here" (86). Implying, in the company of militant Republicans, that people from Northern Ireland are not "really" Irish, Kitty inadvertently puts herself and her partner into a dangerous position.

During their life in Dublin, Kitty attempts to enforce a separation between public and private sectors through the couple's retreat into domestic life. As Danny fails to integrate into Dublin's society because of his Northern Irish background, a happy relationship only seems possible in isolation from the outside world:

Kitty observed with sadness his discomfort and self-alienation. Amongst countryman to whom he purported to belong. Or did they fall into sections and sub-sections and categories of brotherhood? Since she had met him, apart from his Belfast flatmates, Kitty had never really seen Danny at ease with anyone but her, and then primarily in the privacy of her room . . . (47)

However, the "public world of social commitment and political action" (KennedyAndrews 2003: 225) enters the lovers' private life through Danny's involvement in Belfast's Republican milieu. Even in geographical distance he is not capable of breaking free from the city's influence. In this way, the hero gives precedence to the "masculine sector" of political involvement over his private life with his partner (Spivak 1988: 103).
In the final section of the novel, the couple moves to London in an attempt to escape Belfast's destructive influence. Kitty once again tries to hide away into an apolitical private world in order to make Danny cut his ties with Belfast's Republican community. According to Gerry Smyth, Kitty's longing for seclusion is an expression of "a feminine realm of domestic desire as an alternative to patriarchal politics" (1996: 144). Her dream of "domestic privacy", however, is shattered by the unrelenting impact of Belfast on her partner (Cleary 1996: 241). While Kitty makes an effort to blend into London's society, Danny rejects his new home by exhibiting a strong Belfast identity. The characters' different attitudes to London become apparent in their individual use of language. As a social marker, language renders the speaker's situation in society: "Any language, any speech, reflects the attitudes and values of the person using it, the person's social and cultural position, his or her relationship to a particular regional and social community; whether the speaker is an authority or is in some oblique or oppositional relation to authority" (Kennedy-Andrews 2003: 172). In this sense, the partners' way of speaking shows their different willingness to cut loose from their own social backgrounds. In contrast to Kitty, who tries to assimilate linguistically, Danny rejects London through his personal use of language: "There was so much to learn and while she tailored her colloquialism, if nor her accent, in order to make herself understood, she observed that Danny had almost entirely lapsed into that harsh, defensive Belfast dialect he hid behind" (85). Choosing the lingo of working-class Belfast as his mode of expression, Danny disassociates himself from his English environment and his partner who does not belong to the same social class. At the same time, he reinforces a strong bond to his native city. Thus, speaking in Elmer KennedyAndrews words, Danny exhibits his "social and cultural position" as an individual belonging to a different "regional and social community" (2003: 172). The hero's incapacity to disassociate himself from Belfast and his Republican background gives rise to disputes between the two partners and contributes to their estrangement.

When the couple returns to Belfast on a visit, we see O'Riordan utilizing the language 
of Belfast's Republican milieu to expose sociocultural barriers: whereas Danny masters the local terminology, Kitty is unable to decode the double meaning of expressions commonly employed by working-class Republicans. Danny's explanation of punishment methods used by Belfast's paramilitaries, are beyond Kitty's comprehension:

\begin{abstract}
'What's a silver cross - some sort of award?' she asked. 'You could say that.' - Danny pulled his mouth down at the corners, he sounded bitter. He pointed to his elbows, then his knees. 'Back of the knees, back of the elbows job - that's the silver cross sometimes the base of the spine too.' 'You mean bullets?' 'Of course I mean bullets Kitty, sometimes I think you're living in another world ...' (131)
\end{abstract}

Opposing Kitty's lack of understanding to Danny's logic shaped by the Northern Irish conflict, O'Riordan illustrates their incompatible world views. Kitty's incomprehension blatantly shows the misunderstanding of the Northern situation commonly displayed in the South of Ireland.

The end of the novel is marked by Danny leaving his partner on account of his Republican friends and family. With the persistent negative influence of Belfast on the two characters' relationship, O'Riordan implies that in the context of the Northern Irish conflict a love story cannot be detached from politics. The couples' unsuccessful striving to overcome social and cultural boundaries functions as a metaphor for separation and alienation between working and middle-class as well as the two parts of the island. In this sense, Involved cannot be read as a tale of "national reconciliation" (Cleary 1996: 238) but as a critical account of the breach between different social milieus.

As complex variations on Lingard's cycle, Troubles, A Goat's Song and Involved render the Northern Irish tensions using the "Romance-across-the-divide" narrative in different ways. Through the depiction of unhappy, transgressive relationships, the three novels work against Cleary's general conception of boundary crossing love affairs as metaphors for political reunion. Focusing on religious, cultural and social difference, May, Healy and O'Riordan suggest that neither a reconciliation between the two conflicting communities within Northern Ireland, nor a mutual understanding of the two parts of the island belonging to different states can be possible. As to the different settings, a tendency towards a broader depiction of the Northern Irish tensions can be discerned in the three novels examined; whereas in Troubles the plot entirely develops in Northern Ireland, the action in A Goat's Song moves between the North and the South to illustrate the influence of the tensions on both parts of the island. Setting her novel in Northern Ireland, the Republic and England, O'Riordan points to the three parties involved in the conflict. Despite their different choice of settings, all three authors employ Belfast as an indicator for sectarian barriers and use the city as an obstacle for relationships cutting across sociocultural and denominational lines. By highlighting Belfast's destructive influence on the respective love stories, the three novelists reconfirm the prevailing bleak narrative illustrations of the Northern Irish conflict. Although the action in A Goat's Song and Involved takes place against a less violent background than in Troubles, the illustrated sectarian tensions reflect an equally pessimistic view of the situation. Consequently, it becomes evident that despite the beginning settlement of the political situation in Northern Ireland in the nineties, the 'Romance-across-the-divide' is first and foremost utilized to express political disagreement.

\section{Works Cited}

Armstrong, Nancy. 1987. Desire and Domestic Fiction. A Political History of the Novel. Oxford: Oxford University Press.

Cleary, Joe. 1996. "“Fork-Tongued on the Border Bit': Partition and the Politics of Form in Contemporary Narratives on the Northern Irish Conflict”. South Atlantic Quarterly. No. 1. 227276.

1999. "Domestic Troubles: Tragedy and the Northern Ireland Conflict”. South Atlantic Quarterly, Vol. No. 3. 501-537.

Healy, Dermot. 1994. A Goat's Song. London: Penguin.

Howe, Irving. 1971. "The City in Literature". Commentary. Vo. 51. 60-68.

Kennedy-Andrews, Elmer. 2003. Fiction and the Northern Ireland Troubles since 1969: (Deconstructing the North. Dublin: Four Courts Press. 
Lingard, Joan. 1972. Across the Barricades. London: Hamish Hamilton.

Mahony, Hunt, Christina. 1998. Contemporary Irish Literature. Transforming Tradition. New York: St. Martin’s Press.

Morgan, Valerie; Smyth, Marie. 1996. Mixed Marriages in Northern Ireland. Coleraine: Centre for the Study of Conflict, University of Ulster.

May, Naomi. 1976. Troubles. London: John Calder.

O’Riordan, Kate. 1995. Involved. London: Flamingo.

Shields, Rob. 1996. "A Guide to the Urban Representation and What to Do about It: Alternative Traditions of Urban Theory”. Representing the City. Ed. Anthony D. King. London: Macmillan. 227-252.

Smyth, Gerry. 1997. The Novel and the Nation. Studies in the New Irish Fiction. London: Pluto Press.

Spivak, Gayatri. 1988. In Other Worlds: Essays in Cultural Politics. London: Routlege.

Sullivan, Megan. 1999. Women in Northern Ireland: Cultural Studies and Material Conditions. Gainsville: University of Florida Press.

Wonderich, Gefter, Roberta. 1999. “Islands of Ireland. A Tragedy of Separation in Dermot Healy's A Goat's Song”. Northern Narratives. Jordanstown: University of Ulster. 69-86. 